\title{
建長寺に見る古都鎌倉における宗教的谷戸空間の 景観構造に関する研究
}

\author{
A Study of the Landscape Structure of the Religious Valley, Kenchoji in the Old Capital, Kamakura \\ 高橋 睦* 石川 幹子** \\ Chika TAKAHASHI Mikiko ISHIKAWA
}

\begin{abstract}
The purpose of this study is to bring to light the landscape structure of the Yato in Kamakura. It is a fortress city surrounded by hills on the three sides. The hills have various Yato which form and characterize the original landscape of Kamakura. Of the Yato identified on the map, I selected Kenchoji Yato for the object area as the case study of the characteristic religious Yato. Following a study on the relation between the historical transition of Kenchoji and Yato, I attempted to analyze the landscape structure of the Kenchoji Yato from the standpoint of the plane-level landscape and the sequence landscape along the axis of Yato. To clarify the plane-level landscape, I made an inclination classification figure map. To clarify the sequence of landscape, I clarified the landscape structure by taking photos of the landscape and find out the area ratio of each landscape element. The above analysis led me to conclude that there were six characteristics with respect to the landscape structure of Kenchoji Yato.
\end{abstract}

Keywords: Yato, Kenchoji, Landscape structure, Religious area キーワード：谷戸，建長寺，景観構造，宗教的空間

\section{1. 研究の背景と目的}

これからのまちづくりにおいて, 残された歴史的環境をどのよ うに評価し，保全していくかは重要な課題である。そのためには， 建築単体ではなく, 周辺環境を含んだランドスケープ構造を明ら かにすることが必要であり, 分析手法の確立が必要之されている。 東京近郊の歴史都市である鎌倉は，南を海，三方を丘陵に囲ま れた城塞都市である。鎌倉を囲む丘陵は，大小様々な谷戸という 入り組んだ地形によって構成されている。谷戸は鎌倉の特徵であ る古都の景観を構成しているが，地形を無視した開発や谷底部の宅 地化の広がりにより, 多くの谷戸が本来の風景を失ってしまってい る。このように, 变わりゆく社会環境の中で, 古都としての歴史的 環境をどのように保全し, 継承していくかが課題となっている。

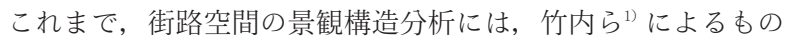
が, 参道空間に関する研究には, 船越ら ${ }^{2)}$ にる空間の物理的構 成要素之心理的作用に関する一連の研究がある。鎌倉の歴史的環 境に関する研究としては, 片山ら ${ }^{3)^{3)} \text { 5) }}$ による建築高度規制に対 する計画手法の確立を目指しているものがある。社寺については, 鎌倉市文化財総合目録編さん委員会 $\left.{ }^{6}\right)$ にって文化財指定されて いる建築が，鎌倉市史編纂委員会 ${ }^{7)}$ によって各社寺の史実が，そ れぞれまとめられている。鎌倉の自然環境については大澤ら ${ }^{8)} に$ よる鎌倉市を対象としたビオトープマップ作成手法に関する研究が ある。歴史的環境を, 地形・景観構造など複合的な観点から分析 したものとしては, 高橋ら ${ }^{9}$ による円覚寺を対象としたものがある。 鎌倉に抢ける谷戸空間の特色は，宅地，宗教的空間が混在して いることにある。本論文の分析の項で明らかにするが, 鎌倉には 社寺を有する谷戸が 66 あり, その中で円覚寺は, 宗教空間が谷 戸谷底部の $75 \%$ を占める唯一例外的な谷戸である。そこで本研 究は, 鎌倉の谷戸の多くを占める社寺と宅地が混在している谷戸 の景観構造を明らかにすることを目的とし, 建長寺の谷戸を対象 として研究を行うこととした。建長寺は, 日本初の純粋な禅の専 門道場であり ${ }^{10)}$, 後の禅宗寺院造営の先駆的な例と考えられてい る。このことより, 先行研究の円覚寺の谷戸と対比させることで,
宗教的谷戸空間の特質を相対化し，比較検討することが可能にな ると考えられる。

\section{2. 研究の方法}

\section{(1) 対象地}

建長寺は，臨済宗建長寺派の大本山であり，鎌倉五山第一位に 指定されている名刹である。鎌倉市中心部から巨福呂坂を過ぎた 北東側に位置し, 北西一南東向きから南西一北東向きに折れ曲がっ た谷戸の内部が，伽藍と塔頭によって構成される寺空間に占有さ れている。建長寺に関する調査研究としては, 滝澤・宮田 ${ }^{11)}{ }^{12)} に$ よって発掘調査報告と伽藍の变遷の考察がなされている。この調 查を基に, 三浦 ${ }^{13)}$ によって建長寺庭園の江戸期の作庭過程が，宮 内・田畑 ${ }^{14)} に よ っ て$ 遺存植物体の分析に基づく植栽について考察 されている。また, 鎌倉期の建長寺の伽藍計画について, 櫻井 ${ }^{15)}$ が建長寺伽藍指図について検討を行っている。しかし，これまで 建長寺の景観構造を内部に展開されている歴史・宗教・自然の関 係から詳細に分析したものはない。以上より，建長寺の谷戸の研 究を行うことは, 宗教的谷戸空間の景観構造をまとめる上で意義 があると考える。

\section{(2) 研究方法}

(i ) 谷戸の抽出

まず，鎌倉市に抢ける谷戸を抽出した。GIS（地理情報システ ム; Arc View 8.2 ESRI 社) の Hydrology Modeling を使用 し，非集水域を除く市域から，集水面積の閾值を 10ha として小 流域を抽出した（図一-1)。そして，土地利用を基に分類を行い， 社寺を有する谷戸の中から建長寺の谷戸を抽出した。 ${ }^{16)}$

\section{（ii）景観構造分析}

次に，建長寺の谷戸の景観構造分析を行った。まず，文献や古 絵図から建長寺の歴史的变遷と谷戸との関係を明らかにした。そ して, 現在の景観構造を, 平面とシークエンス景観から分析した。

平面分析では, 建長寺の谷戸の傾斜区分図を作成し, 地形の特 徵と宗教空間との関連性を明らかにした。シークエンス景観分析 には静止画を使い，景観構成要素を抽出してその面積比を分析す

*慶應義塾大学大学院政策・メディア研究科 **慶應義塾大学環境情報学部 


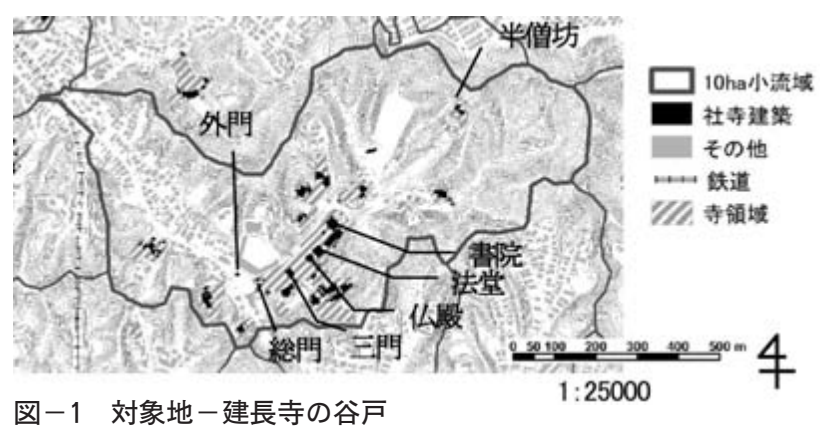

ることで景観構造の抽出を試みた。さらに, 古絵図を基に, 鎌倉 期の景観構造を明らかにすることにより, 現在との比較を試みた。 3. 分析

(1) 谷戸の類型化

現在鎌倉には, 社寺を有する 10 ha 小流域が，旧鎌倉地域を中 心に 66 ある ${ }^{17)}$ 。そこで, 宗教的な谷戸の特徴を明らかにするた めに, 社寺を有する谷戸を, 谷底部の土地利用によって再類型し た。その結果, 社寺を有する谷戸のうち, A. 社寺地が $75 \%$ 以上 占めるものが 1 箇所, B. 社寺地が $75 \%$ 以下 $25 \%$ 以上占めるもの が 12 箇所, C. 社寺地が $25 \%$ 以下のものが 53 箇所抽出された (表-1)。

A に分類された谷戸は円覚寺のみであり, 先行研究で景観構 造を明らかにしている。そこで本研究は, B の谷戸の中から, 円 覚寺之同じ禅宗寺院で, 谷戸の形状が最も良く継承されている建 長寺の谷戸を対象地として, 研究を行うこととした。

表-1 鎌倉における社寺を有する谷戸の類型化

\begin{tabular}{|ll|r|l|}
\hline \multicolumn{2}{|c|}{ 谷底部の土地利用の割合 } & 谷戸数 & \multicolumn{1}{|c|}{ 代表的な社寺 } \\
\hline $\mathrm{A}$ & 社寺地が 75\%以上占めるもの & 1 & 月賞寺 \\
\hline $\mathrm{B}$ & $\begin{array}{l}\text { 社寺地が } 25 \% \text { 以上 } 75 \% \text { 以下占め } \\
\text { るもの }\end{array}$ & 12 & 建長寺、浄妙寺 \\
\hline $\mathrm{C}$ & 社寺地が 25\%以下のもの & 53 & 明月院、高德院大仏、海藏寺 \\
\hline
\end{tabular}

\section{(2) 景観構造分析}

( i ) 歴史的变遷

まず，建長寺の歴史的変遷を分析した。資料には，「鎌倉市史 社寺篇 $\rfloor^{18)}\lceil\text { 史蹟建長寺境内 }\rfloor^{199}\lceil\text { 建長寺 }\lrcorner^{200}$ 之, 「建長寺伽監指図」 $(1331 \text { 年推定 })^{21}$ 「建長寺境内絵図」(1678 年寄進 $)^{22}$ の二つの絵 図を使用した。これらを基に, 建長寺の構造の变遷を図化した (図-2)。

建長寺では, 1253 年の仏殿落慶供養を皮切りに, 約 20 年余り かけて次々と中心伽藍が整備されていった。1279 年には開山蘭 渓道隆の塔所である西来庵が開かれた。山の中腹に位置し, 周辺 の地形が大きく变化していることから, 大規模な造成工事が行わ れたことがわかる。その後, 建長寺は幾度も被災するが, その都 度大規模な復興が行われた。そして, 谷戸中部の広い谷底部に北 東一南西の軸を持つ壮麗な七堂伽藍が整備され, 次々と塔頭が創 建された。建長寺では，1500 年までに確認されているだけで 49 院の塔頭が創建されている。その結果谷戸内の造成が進み, 現在 のような地形になった。

しかし，1414 年 12 月に応永の大火が起きると，その後も続く 被災に対し復興が追いつかなくなり, 建長寺は徐々に衰退してい く。主要伽藍は, 三門や法堂などの単体の再建が行われるのみと なってしまった。一方, 塔頭は 1500 年までに新たに 8 院が開か れている。このように, 谷戸全体の塔頭開発が継続する一方, 中 心伽藍は衰退し, 中心性が薄れていった。江戸時代に入ると幕府 の庇護の下, 三門・仏殿・方丈と次々に復興され, 主要伽藍が揃 えられた。書院の裏にある庭園は, 規模が縮小され現在の大きさ
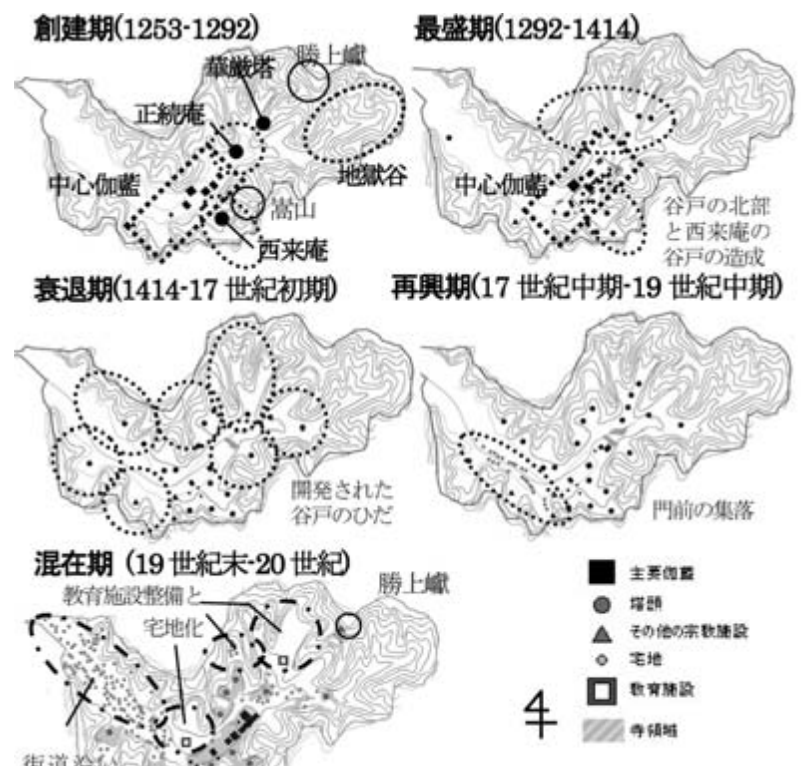

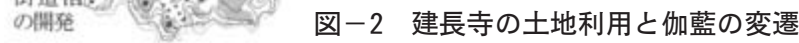

になった23)。しかし，明治に入ると，敷地内に様々なむのが混在 するようになる。外門の外の街道沿いは, 土地の細分化と開発が 進み, 宅地と畑が混在するようになった。また, 境内内の塔頭跡 地の土地む分割され，1922 年には総門脇に建長寺が運営する鎌 倉中学校が建てられ，奥の小さな谷戸にはグラウンドが造成され た。その後, 関東大震災で壊滅的な被害を受けるが, ほとんどの 主要伽藍が移築・再建され, 宅地化も進んだ。創建から約 750 年 経ち，寺空間に様々な施設が見られる現在は，混在期と言える。

以上より, 建長寺では創建から 15 世紀までにすべての塔頭が 創建されたが，開発されたエリアが時代ごとに变化していること がわかった。塔頭の開発は谷戸の北部之西来庵の谷戸内から行わ れた。14 世紀前期までに, 11 院の塔頭が谷戸の北部と東側にあ る西来庵の谷戸に創建された。室町時代に入りさらに塔頭が増え ると, 塔頭の立地に法則性が見られなくなり, 北西一南東の門前 の街道沿いと派生するひだの内部，谷戸の北部などの造成が進ん だ。1 1414 年以降は, 塔頭が存在しているひだのさらに奥まで, 平場の造成が行われている。

谷戸の東側に位置する嵩山は, 建長寺で最初に塔頭が建てられ た場所である。開山蘭溪道隆の西来庵であり，嵩山は建長寺の境 致に指定されている24)。また, 西来庵の約 7 年後に創建されたの は, 円覚寺の開山である無学祖元の正続庵であり, 七堂伽藍の真 北にある奥の空間に開かれている（1334 年に円覚寺に移転, 現 在は正統院が建つ)。谷戸の北部の奥の空間は, 建長寺の奥の院 とされる浄地の谷や処刑場であった地獄谷があり, 華撖塔む建て られている。外門は, 下界と宗教空間を隔てる門であり, 下馬を する場所である。北西一南東の谷戸部は外門の外側であり, 寺域 外である。街道沿いには他寺院・民家などあ存在していることから， 当時の建長寺の境界があいまいだったのではないかと推察される。

（ii）景観構造分析(1) 平面構造

建長寺の谷戸の規模は寺域が約 53,870 平方メートル，南北約 $730 \mathrm{~m}$, 東西約 $1,330 \mathrm{~m}$ の大きさである。谷戸中部で北西一南東 から勝上䛿に向かって南西一北東へと折机曲がっている。

まず，現在の建長寺の谷戸の地形を把握するために，建長寺の 傾斜区分図を, GIS を用いて作成した。傾斜区分は，3 度未満，3 度以上 8 度未満, 8 度以上 15 度未満, 15 度以上 30 度未満, 30 度以上の 5 種に分けた。 ${ }^{25)}$ その結果より, 建長寺の谷戸は 0 度一 8 度の平地之緩斜面によって構成されている幅の広い谷底部之, 15 度以上の急斜面によって構成されていることがわかった。谷 


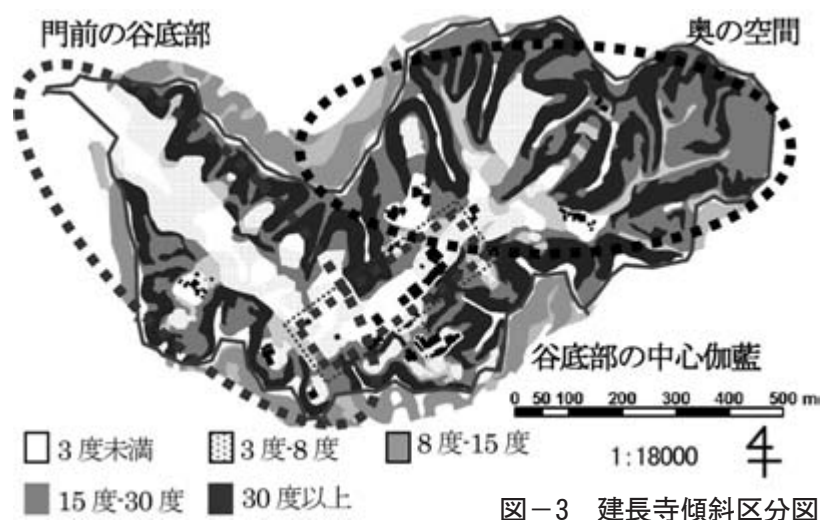

底部の幅を測ると, 県道沿いの北西一南東向きの谷戸部は約 60 $\mathrm{m} \sim 105 \mathrm{~m}$, 主要伽藍のある南西一北東向きの谷戸部は約 $35 \mathrm{~m} \sim$

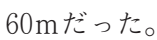

次に, 傾斜区分図と伽藍・塔頭の配置図を重称合わせ, 地形と 宗教空間との関連性をみた (図一 3 )。その結果, 北西一南東に伸 びる伽藍が配置されていない谷底部, 南西一北東に伸びる主要な

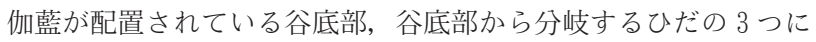
分けられることがわかった。各ひだは平場と周りを囲む急斜面に よって構成されており, 8 度以上の斜面で谷底部と分けられてい ることがわかった。

南西一北東に伸びる谷底部は, 平坦面と緩斜面によって構成さ れている。特に, 主要伽藍である総門・三門・法堂は, 0 度 -3 度の平坦面に建てられている。傾斜がほとんどなく幅が $35 \mathrm{~m} \sim$ $60 \mathrm{~m}$ 之非常に広い。主要な伽藍は一直線上ではなく, 総門一三門, 三門一法堂, 方丈と 3 つの軸を使って配置されているが，これは 地形に合わせたためと考えられる。そして, 緩斜面を隔てて書院 が建てられている。書院は僧の生活空間であり, ここが境界線と なって, 谷戸の北部の奥の空間が展開している。奥の空間は, 複 数のひだによって構成され, 多くの塔頭が創建されてきた空間で ある。分岐するひだは, 谷底部から緩斜面を境にし, 平場と崖地 むしくは極急斜面により囲まれた小空間によって構成されている。 塔頭が創建されるごとに造成が行われ, 平場とそれを囲む急斜面 によって構成される地形ユニットが作られたと考えられる。この ように, 各塔頭は街道・境内というパブリックスペースとの境界 を，斜面を利用することによって明確にし，急斜面に囲まれたひ だごとにプライベートな空間を作りあげているのである。

以上より, 建長寺の谷戸は, 谷戸中腹の広く平坦な谷底地に禅 寺の象徵空間である七堂伽藍を配置し, 書院を境界とした奥の空 間と門前の街道から派生するひだには，小空間によるプライベー 卜な空間がそれぞれ確立されていることがわかった。

（iii）景観構造分析(2) シークェンス景観

(1)方法

次に, 宗教的空間の景観構造を明らかにするために, 参道のシー クエンス景観を抽出した。これは, 伽藍配置が人の視覚という点 からどのような意図から作られ，どのような効果がもたらされて いるか分析するためである。調査場所は, 谷底低地にある外門前 から仏殿までのメインの参道 (ルートA：約 193m) と三門横か ら書院前の唐門まで (ルート B : 約 $104 \mathrm{~m}$ ), 奥の空間である副 参道 (ルート C : 約 $234 \mathrm{~m}$ ), の 3 箇所で行った (図一 4 )。

調査は, 2003 年 12 月, 2004 年 9 月と 10 月の晴れた日に行い, レンズサイズ $35 \mathrm{~mm}$ のデジタルカメラで，レンズを人間の視線 の高さ（約 $150 \mathrm{~cm}$ ) に固定し, 参道の敷石に並行にレンズを向

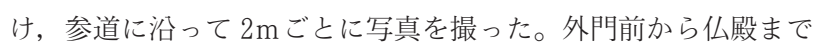
計 99 枚, 山門横から唐門まで計 51 枚, 副参道の入り口から正統 院入り口まで 63 枚と正統院入り口から半僧坊・回春院の分岐点

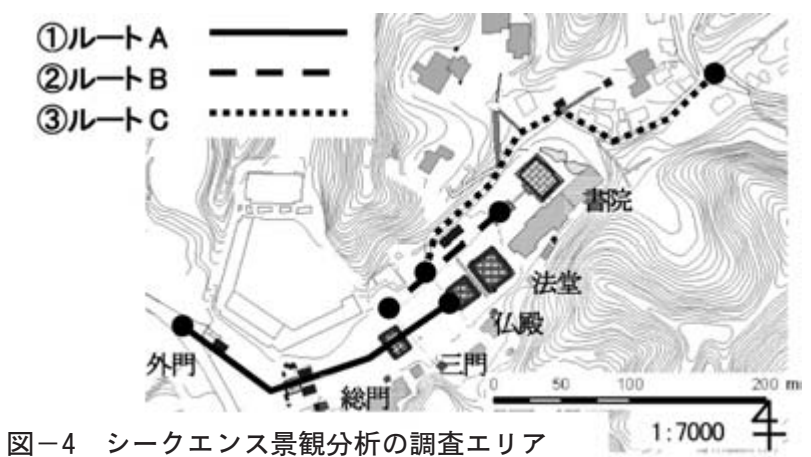

図-4 シークェンス景観分析の調査エリア 表 -2 景観構成要素

\begin{tabular}{|c|c|c|c|}
\hline \multirow[t]{5}{*}{ 自然環境要素 } & \multicolumn{3}{|l|}{ 空 } \\
\hline & \multicolumn{3}{|l|}{ 水 } \\
\hline & \multirow[t]{3}{*}{ 緑 } & \multirow{2}{*}{$\begin{array}{l}\text { 近景の緑（主に常 } \\
\text { 緑樹・背景の緑） }\end{array}$} & 中・遠景の緑 \\
\hline & & & 近景の緑 \\
\hline & & \multicolumn{2}{|c|}{ 植栽（カエデ・サクラ・イチョウ } \\
\hline \multirow[t]{7}{*}{ 人工要素 } & \multicolumn{3}{|c|}{ 歴史的建造物（建築・石碑） } \\
\hline & \multicolumn{3}{|c|}{ 柵·家屋 } \\
\hline & \multicolumn{3}{|c|}{ 崖・人工斜面 } \\
\hline & \multirow[t]{3}{*}{ 道路 } & \multicolumn{2}{|c|}{ 階段 } \\
\hline & & \multicolumn{2}{|c|}{ 参道（石畳・土・白砂） } \\
\hline & & \multicolumn{2}{|c|}{ 舗装道路（コンクリート） } \\
\hline & \multicolumn{3}{|c|}{ 人工物 (景観阻害要素) } \\
\hline
\end{tabular}

まで 58 枚 計 121 枚であった。その中から，景が変化したと思 われるポイントの写真をルートAでは 54 枚, ルート Bでは 18 枚, ルートCでは 28 枚を抽出した。そして, 写真に写っている景観 構成要素を, 自然環境要素と人工要素から計 12 種類に分類した。 緑は, 背景の緑と, 場のポイントとなる植栽を分けて分類した。 さらに, 背景の緑は近景之中遠景に分けた（表一2）。そして，画 像処理ソフトを用い，写真をグリッドで 391 マスに分けて占有し ている要素を塗り分け, 画像に対する景観要素の面積比率を求め た。そして，まずその中から特徴的な要素を抽出し，X軸に参 道の距離をとり, 折れ線グラフにしてその变化を見た。さらに, 画面の景観要素の構成を比較することで, 画面構成にどのような 特徽があるかを見た。また，ルートAについては伽藍指図と比 較することにより，景観構造の变化を見た。

(2)分析結果

（ルートA）谷底部：外門から仏殿まで

まず，ルートAについて分析を行った。景観構成要素を見て みると，12 項目のうち空・歴史的建造物・参道が，常に高い割 合を示した。近景の緑・植栽・中遠景の緑は一部で高い割合を示 した。階段はほとんど見られなかった。

次に，常に高い割合・一部で高い割合を示した 6 項目を見てみ ると, 空・歴史的建造物・近景の緑・植栽で, 特に割合が高くな る箇所が複数あった。それを折れ線グラフにして重ねると，景観 構造が, 外部一外門, 外門一総門, 総門一三門, 三門一仏殿之連 続する4つのエリアに分けられた（図一-5)。

次に，各ェリアの画面構成を比較してみると，総門一三門，三 門一仏殿で特徵的な画面構成となっていることがわかった。現在 総門が建長寺の拝観入口であり, 外門と総門の間は駐車場となっ ているため, 外部から総門にかけては, 特徴的な景観は見られな かった。総門の手前から三門にかけて, 三門が常に視界の中央に 配されていることがわかる。景観構成比を見ると，他のエリアと 比べて空の割合が特に高く, 植栽の割合も高い值を示している。 空は画面上部半分を占め, 左右に中遠景の緑も望める。以上より, 奥行きのある，開放的な空間となっていることがわかる。植栽は 主にサクラで, 参道の両側に燈篭が建ち, ほぼ左右対称な構成上 なっている。これにより, 三門までの参道の軸線が際立つように なっている。参道沿いには庭石も整備されており, 建長寺のエン 
トランス空間として庭園広場のような空間となっている。三門に 近づいていくと, 徐々に視界が覆われ, 門によって切り取られた 次の空間が見えてくる。門を介して見える次の景, さらにその先 に見える仏殿に奥行きが感じられる。三門は場と場の境界であり, 次の空間への入り口となっているのである。門をくぐると, 三門 から仏殿の空間となる。一転して植栽は見られず, 近景の緑が画 面の左右 7 割前後を占めるようになる。これは, 高さ $13 \mathrm{~m} に の$ ぼる 7 株のビャクシンで, 参道之並行に作られている長方形の囲 い庭の中に植えられている。ビャクシンによって絞られた景と直 線の参道と囲い庭によって, 閉じた空間の中で参道の軸が強調さ れた空間となっている。

以上の分析結果より, 建長寺は, 総門一三門, 三門一仏殿と, 異なる 2 つ平面空間を活かした景観構造を持っていることがわ かった。総門から三門は, 平坦面に建てられた歴史的建造物を中 心として, その周囲にほかの景観要素が背景となり, 左右の広が りと外に向かう奥行きが感じられ, 非常に開放的な景観となって いる。左右には植栽・燈篭が配されているが，これらは約 $3 \sim 5$ $\mathrm{m}$ に高さが抑えられて抢り, 配置はほぼ左右対称である。その結 果, 三門は他の景観要素によって隠されることがなく, 常に視界 の中央にあり際立っている。このように, 植栽のボリュームを抑 えることによって中心の三門を引き立たせ, 左右対称にすること によって三門までの参道の軸を強調し, 宗教性を高める効果を作 り出している。門を介して続く三門から仏殿は, 歴史的建造物を 中心に置き, ボリュームのある近景の緑を左右に配すことで閉じ た空間となっている。高低差はないが, 左右にビャクシンを配す ることによって景の絞りを作り出し, 中心に向かって奥行きを感 じさせる効果を作り出している。配置は, 総門から三門同様に, ほぼ左右対称である。ボリュームのある近景の緑を左右に配置す ることで軸を強化し, 見え隠れと絞りの効果により人々を奥へと

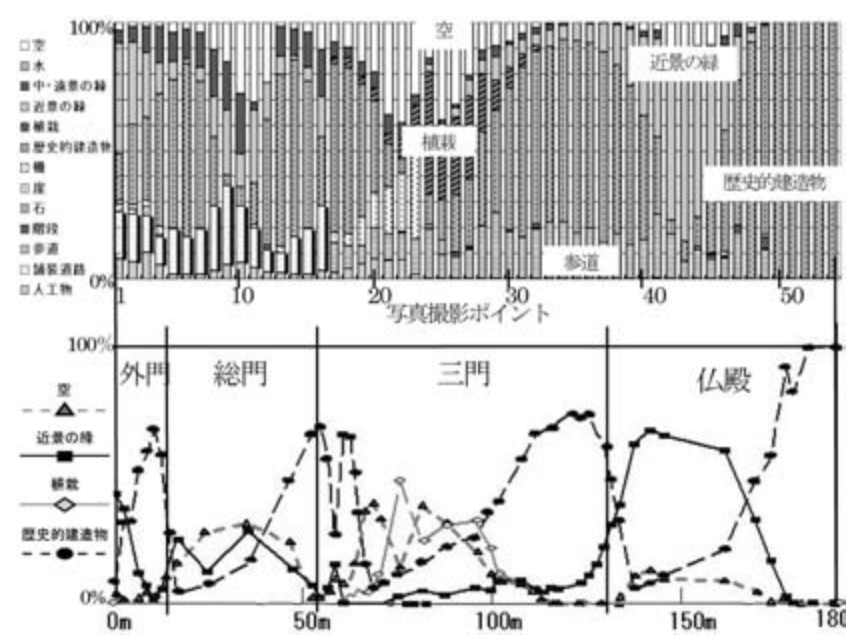

図ー5 ルートAにおける景観構成要素と視覚効果の変化
誘う構成となっている。このように, ボリュームのある近景の緑 による絞りと強調された軸に沿って, 中央に配された仏殿へ, そ して本尊である地蔵菩薩へと誘っていくのである（図一6）。

次に, ルート A の景観構造を, 最も伽藍が整備されていた鎌 倉時代の最盛期と比較した。使用したのは, 1331 年に描かれた と伝えられる建長寺の伽藍指図である。伽藍の配置と大きさは, 1331 年当時から幾度も建て替えられているため, 現在と異なっ ている。そこで, 桜井による考察 ${ }^{26)}$ と発掘調査 ${ }^{27)}$ を基づき, トレー スした絵図の三門から先を 31 度回転させ，現在の地図と重稀合 わせた。そして, 鎌倉期の景観構造と現在の景観構造を比較した (図 $-7 \cdot 8$ )。

伽藍指図では, 総門から建長寺庭園までが描かれている。現存 する総門・三門・仏殿・法堂に加え, 総門之三門の間の左右に東 司之浴室が，三門と仏殿の間の左右には僧堂と庫裏がそれぞれ配 置されており，七堂伽藍が完備されていたことがわかる。また， 参道沿いには, 総門から三門までに 12 株, 三門から仏殿までに 10 株, 計 22 株のビャクシンが描かれている。現在はエントラン スの庭園空間となっている総門と三門の間にはビャクシンが植え られていたことがわかる。さらに, 仏殿前の庭園の周囲は塀之回 廊で囲まれていたことがわかった。

以上より, 当時の総門から仏殿までのエリアは, 近景の緑が視 野を絞り, 軸線を強めているという現在の三門一仏殿間と同じ景 観構造が連続していたと推察された。特に, 三門から仏殿までは 塀之回廊に囲まれている。鎌倉末の早歌「巨山景」に「遥に入始 る山の内, 山皆 (みな) 寺ある寺作り, その唐国を遷し（うつし） きて, 見る心地する是やこの」 $\rfloor^{28)}$ とあるように, 当時の建長寺は 非常に中国的な空間構成だったという ${ }^{29)}$ 。若いビャクシンに現在 ほどのボリュームはなかったと考えられるが, 垂直の延びるビャ クシンを直線沿いに植えることで現在よりもより軸を強調した整 然とした空間であったと想像される。

しかし，伽藍は火災により何度も被害にあった。再興の頻度は 各伽藍により異なり，ほとんどの建築の規模が鎌倉時代から变化
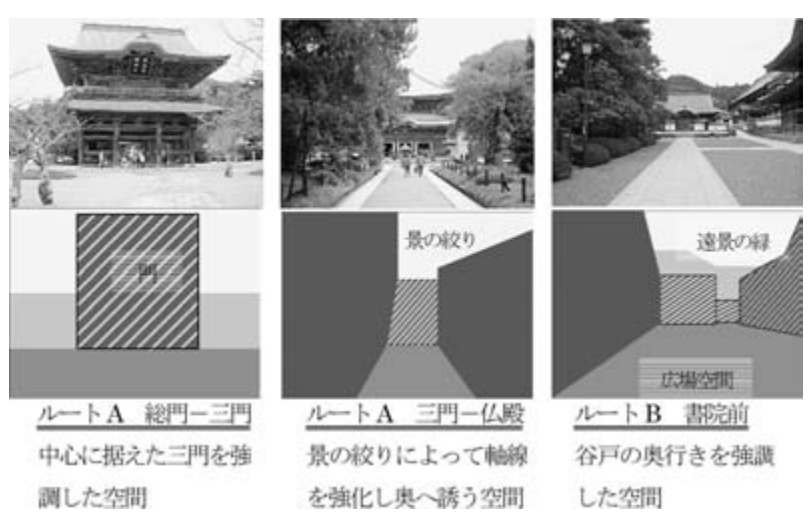

図-6 谷底部の景観構成

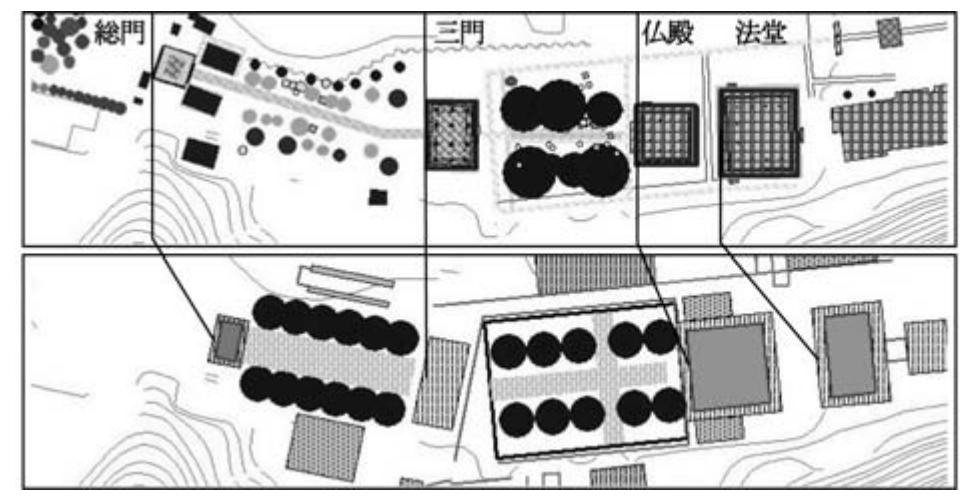

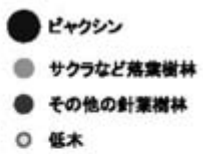

図-7 現況参道図 2004 年

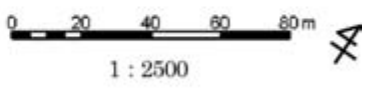

図-8 伽藍指図 1331 年

(トレースしたものを

現況地形に重ねたもの) 
している。加えて, 近年では発掘調査等を元に伽藍や庭園の整備 が行われている。建長寺は, 幾度むの再興や造成により景観構造 を維持しながら, 時代に合わせて景観要素を大きく变化させてい るのである。

(ルート B ) 谷底部：山門横から唐門まで

まず景観構成要素を見てみると, 12 項目の中で高い割合を示 したものは, 空・近景の緑・歴史的建造物・参道の 4 つであった。 中遠景の緑が常に一定の割合を示し, 植栽は一部分だけ高い割合 を示した。そして, 高い割合を示した, 空・近景の緑・歴史的建 造物・中遠景の緑を折れ線グラフにして重ねてみると, 空・近景 の緑・歴史的建造物が, $20 \mathrm{~m}$ 付近から $80 \mathrm{~m}$ 付近にかけて $25 \%$ 前 後とほぼ同じ割合を示していることがわかった（図-9）。

ルート B の書院前は, 左側は近景の緑, 右側は法堂と庫裏で 空間が仕切られ, 縦約 $60 \mathrm{~m}$ 幅約 $15 \mathrm{~m}$ の広い広場空間となってい る。右側に法堂・庫裏につながる敷石が, 左側に書院につながる 敷石がそれぞれ整備されている。勝上䮲の頂を中央にして書院が 配置されており, 敷石一唐門一書院一勝上镉の頂が一直線上に並 んでいる。書院前のどこからでも勝上镉が望めるようになってい る。参道の左側は, 三門一仏殿のようにボリュームのある近景の 緑と植栽で占められている。参道の右側にはなにも設置されてい ないため, 法堂と庫裏がよく見えるようになっている。また，画 面右上部を占める空之書院の奥に見える遠景の緑によって谷戸の奥 行きが感じられる。以上より, ルート B は谷戸の奥行きを強調し た，長方形型の広場空間となっていることがわかった（図一6）。 (ルートC) 副参道

ルート C は, 塔頭・民家・グラウンド・半僧坊へと続く道で ある。途中で右に折れており, 書院横の入り口から正統院, 正統 院から回春院・グラウンド・半僧坊への分岐点と 2 つのエリアに 分けられる。沿道のひだ内には塔頭, 民家, 畑などが点在してい る。景観構成要素を見てみると, 12 の項目のうち, 高い割合を 示したのは, 近景の緑と参道であった。一定して多い近景の緑は, スギなどの植林や斜面の緑など種類は様々で一貫性はない。そし て, 書院横から正統院までは, ひだの高低差があるため植栽と崖・ 人工斜面が大きい割合を占め, 正統院から分岐点までは, 民家が 多いため家屋・柵の割合が高くなっていた。しかし，ルートA のような特定の景観構造が反復するという連続した特徵は見られ なかった（図ー10)。以上のように，ルートCには特徴的な景観 構造の特徵は見られなかった。書院裏は, 16 世紀まで広大な池 のある庭園空間だったことから，昔は開放的な空間だったと考え られる。しかし, 江戸時代に庭園が縮小されて様々な施設が進入 したため, 現在の民家や近景の緑の多い集落のような景観構成に なった。 ${ }^{30)}$

ルート C から分岐する塔頭の小空間へ続く階段では，近景の 緑・階段・門からなるランドスケープ・ユニットが見られた。平 面構造分析で述べたように, 平坦な谷底部と異なり, 塔頭の小空 間は地形の高低差を利用して造成されている。そして, 各塔頭は 門・本殿・庫裏で構成されており, パブリックな参道之階段でつ ないでいる。左右に植えられている近景の緑は，スギなどの針葉 樹林である。垂直に延びる針葉樹林を左右に整列させることで軸 を強調し，垂直に高く参道を囲むことで空間を閉じる効果がある。 そして, 地形の高低差と左右の針葉樹林を用いて, 小空間内を人 の視覚から隠すことによって, 修行・生活空間とパブリック空間 の境界を明確にし，プライベートな空間を保っている。門前と副 参道は, 各塔頭を結ぶアプローチ道であると共に, 江戸時代から 民家や商業施設が並んでいた公共空間である。人が多数往来する 中で, ランドスケープ・ユニットを各塔頭に導入することによっ て，俗世との境界線を明確にしているのである（図-11・12）。

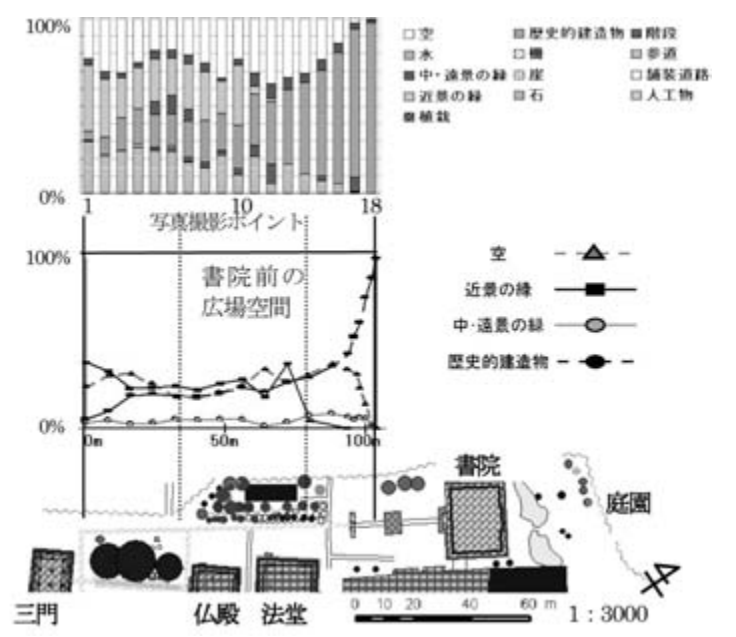

図一9 ルートBにおける景観構成要素と視覚効果の变化
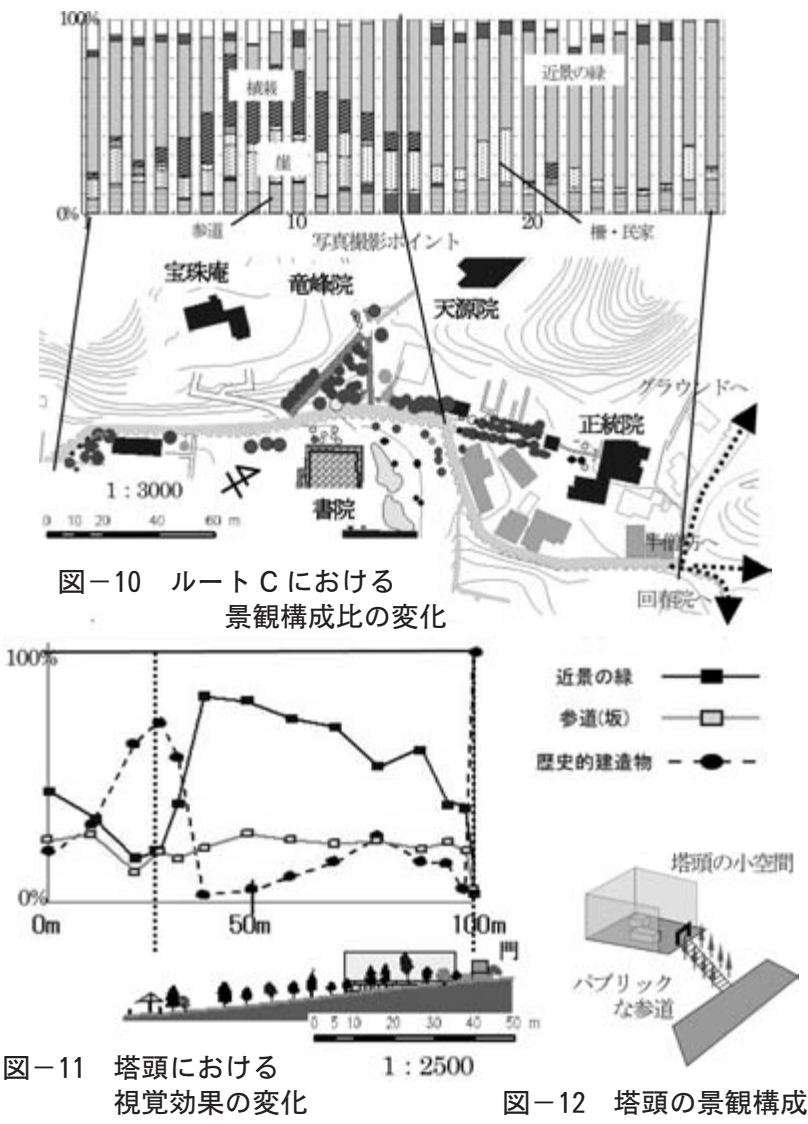

\section{4.まとめ}

以上より，建長寺の谷戸の景観には以下に示す 6 つの景観構造 があることがわかった。

1. 建長寺は, 小流域が宗教空間の領域となっている。

2. 建長寺の歴史的な谷戸空間は, 七堂伽藍の空間, 奥の空間, 門前空間の 3 つのエリアに分けられる。

3. 七堂伽藍のある空間は, 谷戸の平坦な谷底部に位置してお り，門前空間は俗世からの境界となっている。

（i ）入り口である総門から三門は，周囲の植栽のボリュームを 抑え，奥行きのある開放的な空間とすることで中心の三門を際立 たせる景観構造となっている。

（ii）三門から仏殿は, ボリュームのある近景の緑で景が絞られ, 左右対称な構成で軸を強化している。その先の仏殿と参拝対象で ある本尊へ導く期待感を高める効果を生み出している。

（iii）書院前の空間は, 書院の背後にある勝上㖕の頂を常に視界 
の中心に見えるように据え, 谷戸の奥行きと谷底部の広さを強調 する景観構造となっている。

このように, 狭い谷戸の中で異なる 3 つの景観構造を用い, 奥 へと続く宗教的空間の期待感を高めている。

4. 奥の空間は, 時代と共に空間の持つ意味が最も変化した空 間である。創建当初から墓所としての塔頭が創建され, 僧の生活 の場として地形を活かした小空間を作り上げた。16 世紀までは 広大な池を持つ庭園空間を有していたが，時代の流れと共に宅地・ 教育施設などの施設が入り込み, 現在は様々な土地利用が混在化 する空間となっている。

5。門前空間は, 旧街道が通るパブリック空間である。建長寺 の中心部が衰退すると俗世之の境界が薄れ, 塔頭の開発が門前ま で進出し, 建長寺の宗教空間が染み出した。現在は宅地化が進み, 派生するひだ内にある塔頭と民家や商業施設が混在している。

6 . 塔頭の小空間は, 階段・近景の緑・門によるランドスケー プ・ユニットが導入されている。さらに, パブリックな参道とそ こから分岐する小空間は, 地形の高低差を活かし, 参道からの視 界を限定することで俗世界との領域の違いを明確にし, 狭い谷戸 の中でプライベートな空間を作り上げている。

以上のように, 建長寺の谷戸は, 小流域を中心とした重層的な 空間構造を持ち，奥行きのある多様な宗教空間を創りあげている。 限定された領域に, 上に示した 6 つの景観構成手法が密接に関係 しあい，エリアごとに内在する宗教性を体現する景観構造を作り 出している。先行研究の円覚寺の谷戸と比較してみると, 共通点 としては, (1)谷戸の地形そのものが重層的な景観構造の枠組みを 構成している点, (2)七堂伽藍の空間と塔頭の景観構成が基本的に 同じである点が挙げられる。相違点としては, (3)奥の空間が円覚 寺では僧の生活・修行の場として継承されているのに対し, 建長 寺では時代の変化の中で様々な土地利用が混在する空間となって いる点, (4)建長寺では門前空間に宗教空間が染み出しているが, 宗教空間としての特色が希薄になっている点が挙げられる。

以上のように, 円覚寺・建長寺の宗教的空間では, 領域を規定 する地形構造とコアとなる七堂伽藍の構成が, 時代の変化に対し て永続的に維持されてきたことがわかった。さらに，これらを支 える景観構成とシークエンスは, 地形条件が異なっていても同様 の目的と効果を有し, 宗教空間へ人々を誘導している。一方で,

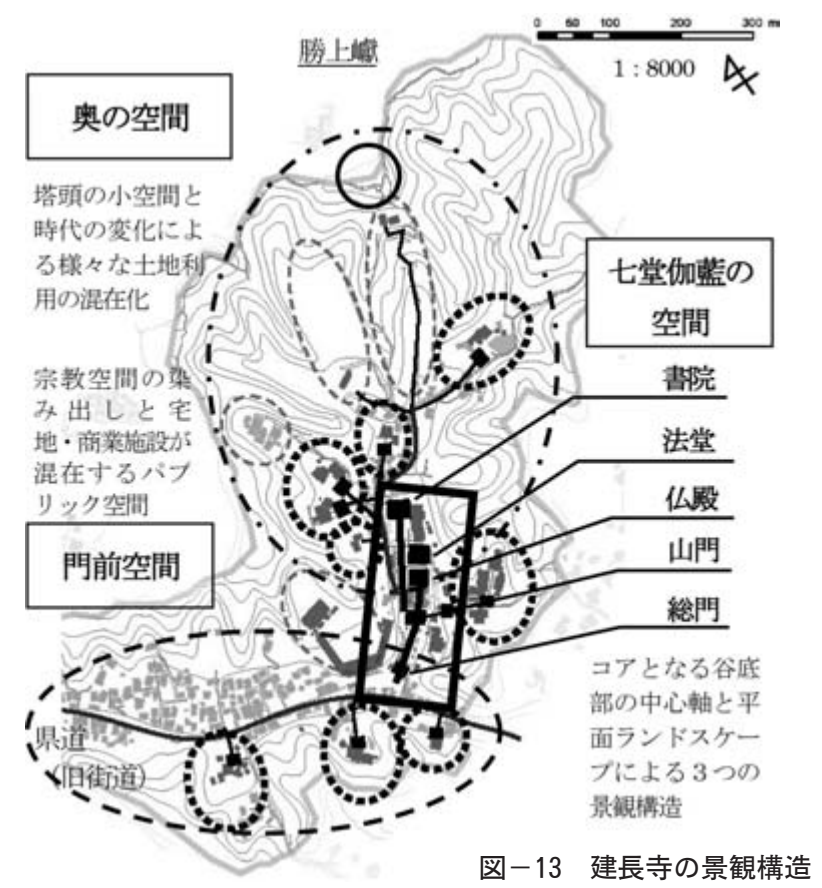

奥の空間と門前空間における私的土地所有による谷戸の細分化之 無原則な開発については谷戸ごとに状況が異なっている。一連の 学術研究の成果を踏まえた景観構造の原則などを踏まえ, 適切な 景観計画を策定していくことが今後の課題と考えられる。

謝辞

本研究をまとめるにあたり，建長寺法務部長田原氏，鎌倉国宝 館の皆様には多くの御協力を頂きました。皆様に厚く御礼申し上 げます。

\section{補注及び引用文献}

1) 竹内・藤本・三橋（1995）：シークエンス景観と連続シーン景観の評 価構造分析 農山村地域に扮ける景観評価に関する研究 その 1 : 日 本建築学会計画系論文集第 475 号, 119-128

2 ）船越・積田（1988）：参道空間の分節之空間構成要素の分析（分節点 分析・物質量分析）—参道空間の研究（その1）：日本建築学会計画 系論文報告集第 384 号，53-62

3 ) 片山 律（1993）：歴史的都市における都市景観評価と計画手法に関 する研究 : 第 28 回日本都市計画学会学術研究論文集, 547-551

4 ）片山 律（1995）：歴史的都市に扔ける都市景観評価と計画手法に関 する研究 : 第 30 回日本都市計画学会学術研究論文集, 259-263

5 ) 片山 律 (1997) : 歴史的都市における都市景観評価と計画手法に関 する研究 : 第 32 回日本都市計画学会学術研究論文集，25-31

6 ）鎌倉市文化財総合目録編さん委員会（1987）：鎌倉市文化財総合目録 建造物篇 : 同朋舎出版, $858 \mathrm{pp}$

7 ）鎌倉市史編纂委員会（1958）：鎌倉市史 社寺編：吉川弘文館, $472 \mathrm{pp}$

$8 ）$ 大澤・山下・森・石川（2003）：鎌倉市を事例とした市域スケールで のビオトープ地図の作成：ランドスケープ研究 67(5)：日本造園学会, 581-586

9 ）高橋・石川（2003）：円覚寺に見る古都鎌倉における谷戸空間の景観 構造に関する研究：ランドスケープ研究 67(5) : 日本造園学会, 659664

10）高木宗監(1989）：建長寺史：大本山建長寺，700pp

11）滝澤・宮田（2003）：史跡建長寺境内 得月楼（客殿）建設に伴う発 掘調査報告書遺構編 : 鶴見大学史跡建長寺境内発掘調査団 - (有)博通, $209 \mathrm{pp}$

12）滝澤晶子（2003）：史跡建長寺境内 下水道敷設に伴うトレンチ調查 報告書：鶴見大学史跡建長寺境内発掘調查団・(有)博通, $106 \mathrm{pp}$

13）三浦彩子（2002）：建長寺蔵『龍王殿再建日記』に見る江戸期作庭の 実証的研究：日本建築学会計画系論文集第 559 号, 263-268

14）宮内・田畑（2002）：遺存植物体の分析に基づく鎌倉期建長寺庭園の 植栽に関する考察：ランドスケープ研究 $65,431-434$

15）櫻井敏雄（1985）：建長寺伽藍の設計計画について：日本建築学会計 画系論文報告集第 350 号，95-104

16）高橋・石川（2003）：円覚寺に見る古都鎌倉における谷戸空間の景観 構造に関する研究：ランドスケープ研究 67(5), 659-664

17）高橋・石川（2003）：円覚寺に見る古都鎌倉に扔ける谷戸空間の景観 構造に関する研究 : ランドスケープ研究 67(5), 659-664 に基づき表 1 を作成。

18）鎌倉市史編纂委員会（1958）：鎌倉市史 社寺編：吉川弘文館, $472 \mathrm{pp}$

19）滝澤・宮田（2003）：史跡建長寺境内 得月楼（客殿）建設に伴う発 掘調査報告書遺構編 : 鶴見大学史跡建長寺境内発掘調査団・(有)博通, 209pp

20）大本山建長寺 (1999）：建長寺：大本山建長寺, 69pp

21）補注 8 ）史跡建長寺境内の添付資料を参照

22）建長寺から提供していただいた現物の写真を参照

23）滝澤・宮田（2003）：史跡建長寺境内 得月楼（客殿）建設に伴う発 掘調査報告書遺構編：鶴見大学史跡建長寺境内発掘調査団・(有)博通, 209pp

24）玉村竹二(1983)：扶桑五山記三 建長寺：片岡英二，110-130

25）国土地理調査研究会編（1992）：土地・水情報の基礎と応用：古今書 院, 300pp

26）櫻井敏雄（1985）：建長寺伽藍の設計計画について：日本建築学会計 画系論文報告集第 350 号, 95-104

27）滝澤・宮田（2003）：史跡建長寺境内 得月楼（客殿）建設に伴う発 掘調査報告書遺構編 : 鶴見大学史跡建長寺境内発掘調査団 - (有)博通, $209 p p$

28）外山久江 (1993)：早歌全詩集 : 三弥井書店, $360 \mathrm{pp}$

29）三山進（1988）：図説日本の仏教 4 鎌倉仏教：新潮社, 381pp

30）滝澤・宮田（2003）：史跡建長寺境内 得月楼（客殿）建設に伴う発 掘調査報告書遺構編: 鶴見大学史跡建長寺境内発掘調査団 - 有)博通, $209 \mathrm{pp}$ 